\title{
PENDATAAN KAWASAN KUMUH PADA KELURAHAN BANGUN JAYA DAN MUARA LAKITAN KABUPATEN MUSI RAWAS
}

\author{
Norma Puspita'), Achmad Djunaidi'2) \\ 1), 2)Program Studi Teknik Sipil, Universitas Indo Global Mandiri \\ Jl. Jend Sudirman No. 629 KM 3.5 Palembang, Kode pos : 30129 \\ Email : norma.puspita@uigm.ac.id ${ }^{1)}$, adjunaidi5@gmail.com ${ }^{23}$
}

\begin{abstract}
ABSTRAK
Penanganan kawasan permukiman kumuh sesungguhnya perlu dilakukan tidak saja di kawasankawasan permukiman kumuh yang menjadi bagian kota metropolitan dan atau kota besar, tetapi juga perlu dilakukan di kawasan-kawasan permukiman kumuh yang ada di kota sedang dan kecil. Pendataan kawasan permukiman kumuh dilakukan di wilayah Kelurahan Bangun Jaya kecamatan BTS Ulu dan Kelurahan Muara Lakitan Kecamatan Muara Lakitan, yang bertujuan untuk mengetahui tingkat kekumuhan pada wilayah ini dan dapat menjadi rujukan pemerintah daerah dalam melakukan penanganan kawasan kumuh. Pendataan dan penentuan tingkat kekumuhan dilakukan berdasarkan Peraturan Menteri Pekerjaan Umum dan Perumahan Rakyat Nomor 2 tahun 2016 tentang Peningkatan Kualitas Terhadap Perumahan Kumuh dan Pemukiman Kumuh. Berdasarkan hasil analisa diketahui bahwa tingkat kekumuhan pada wilayah Kelurahan bangun jaya dan Muara lakitan adalah tingkat kekumuhan sedang dengan nilai kekumuhan sebesar 69. Sehingga penangan kawasan kumuh dapat dilakukan dengan menitikberatkan pada indikator - indikator penyebab kekumuhan yang dominan.
\end{abstract}

Kata kunci : Kumuh, Permukiman, Musi Rawas.

\section{PENDAHULUAN}

Penanganan kawasan permukiman kumuh sesungguhnya perlu dilakukan tidak saja di kawasankawasan permukiman kumuh yang menjadi bagian kota metropolitan dan atau kota besar, tetapi juga perlu dilakukan di kawasan-kawasan permukiman kumuh yang ada di kota sedang dan kecil. Meluasnya Permukiman kumuh di perkotaan telah menimbulkan dampak pda peningkatan frekuensi bencana kebakara dan banjir, meningkatnya potensi kerawanan dan konflik sosial serta menurunnya tingkat kesehatan masyarakat, menurunnya kualitas pelayanan prasarana dan sarana pemukiman, dan lain sebagainya. Kawasan permukiman kumuh yang tidak segera di tangani akan meluas dan perlu dengan segera ditangani, sehingga diharapkan terwujud suatu lingkungan perumahan dan permukiman yang layak huni dalam lingkungan yang sehat,aman,serasi dan teratur.

Sasaran Pendataan lokasi kawasan permukiman kumuh diutamakan pada kawasan-kawasan hinterland kota metropolitan yang ada di daerah penyangga. Meskipun demikian, melalui Pendataan ini sangat dimungkinkan untuk ditemukan kawasan-kawasan permukiman kumuh di daerah penyangga yang bukan kawasan hinterland. Dalam hal ini daerah hinterland yang terkait pada kawasan permukiman kumuh di wilayah kabupaten meliputi daerah kelurahan yang merupakan ibukota dari kecamatan yang menjadi sentra pemerintahan, interaksi sosial serta ekonomi sebuah kawasan.

Kegiatan pendataan permukiman kumuh di lakukan pada Kelurahan Muara Lakitan Kecamatan Muara Lakitan dan Kelurahan Bangun Jaya Kecamatan BTS Ulu (Cecar) Kabupaten Musi Rawas.

\section{METODE PELAKSANAAN PENGABDIAN}

Pertimbangan pemilihan lokasi kawasan permukiman kumuh yang memerlukan penanganan dan prioritas, sebagai berikut:

a. Kawasan permukiman yang berada dibawah standar rata-rata dari segi income pendapatan (masyarakat prasejahtera dan prasejahtera I);

b. Lokasi kawasan permukiman yang sering mendapatkan ancaman banjir perkotaan; 
c. Lingkungan kawasan permukiman yang berada diatas tanah legal dan illegal dan tidak memenuhi persyaratan estetika lingkungan;

d. Lokasi yang ditetapkan berdasarkan arahan Rencana Tata Ruang Kabupaten Musi Rawas, berdasarkan fungsi dan peran yang diemban sebagai kawasan permukiman kumuh;

e. Kawasan yang memiliki nilai fungsional strategis akan tetapi dari kondisi lingkungan kurang memenuhi persyaratan;

f. Kawasan permukiman yang kurang mendapatkan penanganan dari segi sarana dan prasarana;

g. Kawasan permukiman yang berada diatas kepadatan antara 250 - 750 jiwa/ha;

h. Lebih dari $60 \%$ rumah/kurang layak huni; dan

i. Pendataan permasalahan sosial kemasyarakatan tidak terlalu besar.

Kegiatan pendataan kawasan permukiman kumuh ini mengacu pada Peraturan Menteri PU No. 2 Tahun 2016 tentang Peningkatan Kualitas Terhadap Perumahan Kumuh dan Permukiman Kumuh yang menilai tingkat kekumuhan permukiman berdasarkan 7 kriteria, antara lain:
1) Bangunan gedung
2) Jalan lingkungan
3) Sumber air minum
4) Drainase lingkungan
5) Pengelolaan air limbah
6) Persampahan
7) Proteksi kebakaran

Tahapan pelaksanaan kegiatan pengabdian pendataan kawasan permukiman kumuh di Kelurahan Bangun Jaya Kecamatan BTS Ulu (Cecar) Kabupaten Musi Rawas, sebagai berikut:

1) Penentuan lokasi kegiatan

2) Koordinasi tim PKM dengan aparat setempat

3) Penyusunan format kuisioner yang akan disebar kepada responden, dengan jumlah responden 60 orang.

4) Survey lapangan, yaitu penyebaran kuisioner, dan pengamatan lapangan terhadap indikator indikator kekumuhan.

5) Analisa pembobotan tingkat kekumuhan berdasarkan hasil survey lapangan

6) Penentuan klasifikasi tingkat kekumuhan permukiman

7) Delineasi kawasan kumuh dalam bentuk peta kawasan permukiman kumuh.

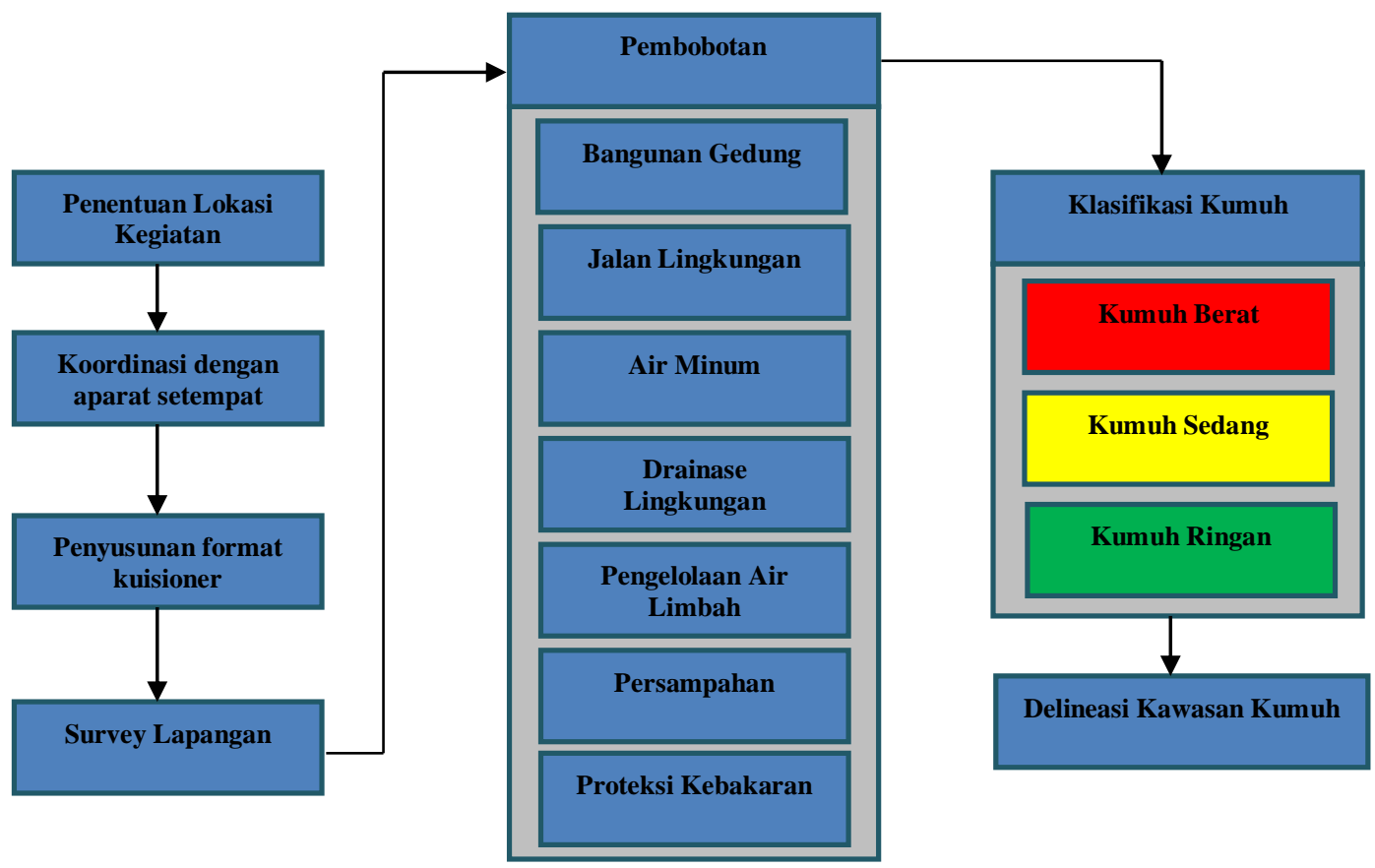

Gambar 1. Metode Pelaksanaan Kegiatan Pengabdian 


\section{HASIL DAN PEMBAHASAN}

Hasil penilaian kriteria kekumuhan menunjukkan bahwa tingkat kekumuhan pada kegiatan pendataan kawasan permukiman kumuh Kelurahan Bangun Jaya Kecamatan BTS Ulu (Cecar) Kabupaten Musi Rawas menunjukkan tingkat Kekumuhan Sedang dengan total nilai kondisi kekumuhan 69, Nilai 9 untuk tingkat sedang pada kriteria pertimbangan lain, dan status tanah tidak legal dalam hal ini dikarena membangun pada lahan tidak sesuai peruntukkan.

Tabel 1. Penilaian Kriteria Kekumuhan

\begin{tabular}{|c|c|c|c|c|}
\hline Kriteria & Indikator & Parameter & Nilai & $\begin{array}{c}\text { Kel } \\
\text { Bangun } \\
\text { Jaya }\end{array}$ \\
\hline \multirow[b]{3}{*}{$\begin{array}{l}\text { Ketidakteraturan } \\
\text { Bangunan }\end{array}$} & \multirow{3}{*}{$\begin{array}{l}\text { - Tidak memenuhi ketentuan tata } \\
\text { bangunan dalam RDTR, } \\
\text { meliputi pengaturan bentuk, } \\
\text { besaran, perletakan, dan } \\
\text { tampilan bangunan pada suatu } \\
\text { zona; dan/atau } \\
\text { - Tidak memenuhi ketentuan tata } \\
\text { bangunan dan tata kualitas } \\
\text { lingkungan dalam RTBL, } \\
\text { meliputi pengaturan blok } \\
\text { lingkungan, kapling, bangunan, } \\
\text { ketinggian dan elevasi lantai, } \\
\text { konsep identitas lingkungan, } \\
\text { konsep orientasi lingkungan, } \\
\text { dan wajah jalan. }\end{array}$} & $\begin{array}{l}76 \% \text { - } 100 \% \text { bangunan } \\
\text { pada lokasi tidak } \\
\text { memiliki keteraturan }\end{array}$ & 5 & 5 \\
\hline & & $\begin{array}{l}51 \% \text { - } 75 \% \text { bangunan } \\
\text { pada lokasi tidak } \\
\text { memiliki keteraturan }\end{array}$ & 3 & \\
\hline & & $\begin{array}{l}25 \%-50 \% \text { bangunan } \\
\text { pada lokasi tidak } \\
\text { memiliki keteraturan }\end{array}$ & 1 & \\
\hline \multirow{3}{*}{$\begin{array}{l}\text { Tingkat Kepadatan } \\
\text { Bangunan }\end{array}$} & \multirow{3}{*}{$\begin{array}{l}\text { KDB melebihi ketentuan RDTR, } \\
\text { dan/atau RTBL; } \\
\text { KLB melebihi ketentuan dalam } \\
\text { RDTR, dan/atau RTBL; } \\
\text { dan/atau } \\
\text { Kepadatan bangunan yang tinggi } \\
\text { pada lokasi, yaitu: } \\
\text { - untuk kota metropolitan } \\
\text { dan kota besar }>250 \\
\text { unit/Ha } \\
\text { - } \quad \text { untuk kota sedang dan kota } \\
\text { kecil >200 unit/Ha }\end{array}$} & $\begin{array}{l}76 \%-100 \% \text { bangunan } \\
\text { memiliki lepadatan tidak } \\
\text { sesuai ketentuan }\end{array}$ & 5 & \\
\hline & & $\begin{array}{l}51 \%-75 \% \text { bangunan } \\
\text { memiliki lepadatan tidak } \\
\text { sesuai ketentuan }\end{array}$ & 3 & 3 \\
\hline & & $\begin{array}{l}25 \%-50 \% \text { bangunan } \\
\text { memiliki lepadatan tidak } \\
\text { sesuai ketentuan }\end{array}$ & 1 & \\
\hline \multirow{3}{*}{$\begin{array}{l}\text { Kualitas Bangunan } \\
\text { Yang Tidak } \\
\text { Memenuhi Syarat }\end{array}$} & \multirow{3}{*}{$\begin{array}{l}\text { Kualitas bangunan yang tidak } \\
\text { memenuhi persyaratan: } \\
\text { - pengendalian dampak } \\
\text { lingkungan } \\
\text { - pembangunan bangunan } \\
\text { gedung di atas dan/atau di } \\
\text { bawah tanah, air dan/atau } \\
\text { prasarana/sarana umum } \\
\text { - keselamatan bangunan gedung } \\
\text { - kesehatan bangunan gedung } \\
\text { - kenyamanan bangunan gedung } \\
\text { - kemudahan bangunan gedung }\end{array}$} & $\begin{array}{l}76 \% \text { - } 100 \% \text { bangunan } \\
\text { pada lokasi tidak } \\
\text { memenuhi persyaratan } \\
\text { teknis }\end{array}$ & 5 & \\
\hline & & $\begin{array}{l}51 \%-75 \% \text { bangunan } \\
\text { pada lokasi tidak } \\
\text { memenuhi persyaratan } \\
\text { teknis }\end{array}$ & 3 & 3 \\
\hline & & $\begin{array}{l}25 \% \text { - } 50 \% \text { bangunan } \\
\text { pada lokasi tidak } \\
\text { memenuhi persyaratan } \\
\text { teknis }\end{array}$ & 1 & \\
\hline $\begin{array}{l}\text { Cakupan Pelayanan } \\
\text { Jalan Lingkungan }\end{array}$ & $\begin{array}{l}\text { Sebagian lokasi perumahan atau } \\
\text { permukiman tidak terlayani } \\
\text { dengan jalan lingkungan yang }\end{array}$ & $\begin{array}{l}76 \%-100 \% \text { area tidak } \\
\text { terlayani oleh jaringan } \\
\text { jalan lingkungan }\end{array}$ & 5 & \\
\hline
\end{tabular}




\begin{tabular}{|c|c|c|c|c|}
\hline Kriteria & Indikator & Parameter & Nilai & $\begin{array}{c}\text { Kel } \\
\text { Bangun } \\
\text { Jaya }\end{array}$ \\
\hline & sesuai dengan ketentuan teknis & $\begin{array}{l}51 \%-75 \% \text { area tidak } \\
\text { terlayani oleh jaringan } \\
\text { jalan lingkungan }\end{array}$ & 3 & \\
\hline & & $\begin{array}{l}25 \%-50 \% \text { area tidak } \\
\text { terlayani oleh jaringan } \\
\text { jalan lingkungan }\end{array}$ & 1 & 1 \\
\hline \multirow{3}{*}{$\begin{array}{l}\text { Kualitas Permukaan } \\
\text { Jalan Lingkungan }\end{array}$} & \multirow{3}{*}{$\begin{array}{l}\text { Sebagian atau seluruh jalan } \\
\text { lingkungan terjadi kerusakan } \\
\text { permukaan jalan pada lokasi } \\
\text { perumahan atau permukiman }\end{array}$} & $\begin{array}{l}76 \%-100 \% \text { area } \\
\text { memiliki kualitas } \\
\text { permukaan jalan yang } \\
\text { buruk }\end{array}$ & 5 & \\
\hline & & $\begin{array}{l}51 \%-75 \% \text { area memiliki } \\
\text { kualitas permukaan jalan } \\
\text { yang buruk }\end{array}$ & 3 & \\
\hline & & $\begin{array}{l}25 \%-50 \% \text { area memiliki } \\
\text { kualitas permukaan jalan } \\
\text { yang buruk }\end{array}$ & 1 & 1 \\
\hline \multirow{3}{*}{$\begin{array}{l}\text { Ketidaktersediaan } \\
\text { Akses Aman Air } \\
\text { Minum }\end{array}$} & \multirow{3}{*}{$\begin{array}{l}\text { Masyarakat pada lokasi } \\
\text { perumahan dan permukiman } \\
\text { tidak dapat mengakses air } \\
\text { minum yang memiliki kualitas } \\
\text { tidak berwarna, tidak berbau, } \\
\text { dan tidak berasa }\end{array}$} & $\begin{array}{l}76 \%-100 \% \text { populasi } \\
\text { tidak dapat mengakses } \\
\text { air minum yang aman }\end{array}$ & 5 & \\
\hline & & $\begin{array}{l}51 \%-75 \% \text { populasi } \\
\text { tidak dapat mengakses } \\
\text { air minum yang aman }\end{array}$ & 3 & 3 \\
\hline & & $\begin{array}{l}25 \%-50 \% \text { populasi } \\
\text { tidak dapat mengakses } \\
\text { air minum yang aman }\end{array}$ & 1 & \\
\hline \multirow{3}{*}{$\begin{array}{l}\text { Tidak Terpenuhinya } \\
\text { Kebutuhan Air } \\
\text { Minum }\end{array}$} & \multirow{3}{*}{$\begin{array}{l}\text { Kebutuhan air minum } \\
\text { masyarakat padalokasi } \\
\text { perumahan atau permukiman } \\
\text { tidak mencapai minimal } \\
\text { sebanyak } 60 \text { liter/orang/hari }\end{array}$} & $\begin{array}{l}76 \% \text { - } 100 \% \text { populasi } \\
\text { tidak terpenuhi } \\
\text { kebutuhan air minum } \\
\text { minimalnya }\end{array}$ & 5 & \\
\hline & & $\begin{array}{l}51 \% \text { - } 75 \% \text { populasi } \\
\text { tidak terpenuhi } \\
\text { kebutuhan air minum } \\
\text { minimalnya }\end{array}$ & 3 & \\
\hline & & $\begin{array}{l}25 \% \text { - } 50 \% \text { populasi } \\
\text { tidak terpenuhi } \\
\text { kebutuhan air minum } \\
\text { minimalnya }\end{array}$ & 1 & 1 \\
\hline \multirow{3}{*}{$\begin{array}{l}\text { Ketidakmampuan } \\
\text { Mengalirkan } \\
\text { Limpasan Air }\end{array}$} & \multirow{3}{*}{$\begin{array}{l}\text { Jaringan drainase lingkungan } \\
\text { tidak mampu mengalirkan } \\
\text { limpasan air sehingga } \\
\text { menimbulkan genangan dengan } \\
\text { tinggi lebih dari } 30 \mathrm{~cm} \text { selama } \\
\text { lebih dari } 2 \text { jam dan terjadi lebih } \\
\text { dari } 2 \text { kali setahun }\end{array}$} & $\begin{array}{l}76 \%-100 \% \text { area terjadi } \\
\text { genangan }>30 \mathrm{~cm},>2 \text { jam } \\
\text { dan }>2 x \text { setahun }\end{array}$ & 5 & \\
\hline & & $\begin{array}{l}51 \%-75 \% \text { area terjadi } \\
\text { genangan }>30 \mathrm{~cm},>2 \text { jam } \\
\text { dan }>2 \times \text { setahun }\end{array}$ & 3 & 3 \\
\hline & & $\begin{array}{l}25 \%-50 \% \text { area terjadi } \\
\text { genangan }>30 \mathrm{~cm},>2 \text { jam } \\
\text { dan }>2 \times \text { setahun }\end{array}$ & 1 & \\
\hline \multirow[t]{2}{*}{$\begin{array}{l}\text { Ketidaktersediaan } \\
\text { Drainase }\end{array}$} & \multirow{2}{*}{$\begin{array}{l}\text { Tidak tersedianya saluran } \\
\text { drainase lingkungan pada } \\
\text { lingkungan perumahan atau } \\
\text { permukiman, yaitu saluran } \\
\text { tersier }\end{array}$} & $\begin{array}{l}76 \%-100 \% \text { area tidak } \\
\text { tersedia drainase } \\
\text { lingkungan }\end{array}$ & 5 & 5 \\
\hline & & $\begin{array}{l}51 \%-75 \% \text { area tidak } \\
\text { tersedia drainase } \\
\text { lingkungan }\end{array}$ & 3 & \\
\hline
\end{tabular}




\begin{tabular}{|c|c|c|c|c|}
\hline Kriteria & Indikator & Parameter & Nilai & $\begin{array}{c}\text { Kel } \\
\text { Bangun } \\
\text { Jaya }\end{array}$ \\
\hline & & $\begin{array}{l}25 \%-50 \% \text { area tidak } \\
\text { tersedia drainase } \\
\text { lingkungan }\end{array}$ & 1 & \\
\hline \multirow{3}{*}{$\begin{array}{l}\text { Ketidakterhubunga } \\
\text { n dengan Sistem } \\
\text { Drainase Perkotaan }\end{array}$} & \multirow{3}{*}{$\begin{array}{l}\text { Saluran drainase lingkungan } \\
\text { tidak terhubung dengan saluran } \\
\text { pada hirarki di atasnya sehingga } \\
\text { menyebabkan air tidak dapat } \\
\text { mengalir dan menimbulkan } \\
\text { genangan }\end{array}$} & $\begin{array}{l}76 \%-100 \% \text { drainase } \\
\text { lingkungan tidak } \\
\text { terhubung dengan } \\
\text { hirarki di atasnya }\end{array}$ & 5 & 5 \\
\hline & & $\begin{array}{l}\text { 51\% - 75\% drainase } \\
\text { lingkungan tidak } \\
\text { terhubung dengan } \\
\text { hirarki di atasnya }\end{array}$ & 3 & \\
\hline & & $\begin{array}{l}25 \%-50 \% \text { drainase } \\
\text { lingkungan tidak } \\
\text { terhubung dengan } \\
\text { hirarki di atasnya }\end{array}$ & 1 & \\
\hline \multirow{3}{*}{$\begin{array}{l}\text { Tidak } \\
\text { Terpeliharanya } \\
\text { Drainase }\end{array}$} & \multirow{3}{*}{$\begin{array}{l}\text { Tidak } \\
\text { dilaksanakannyapemeliharaan } \\
\text { saluran drainase lingkungan pada } \\
\text { lokasi perumahan atau } \\
\text { permukiman,baik: } \\
\text { 1. pemeliharaan rutin; dan/atau } \\
\text { 2. pemeliharaan berkala }\end{array}$} & $\begin{array}{l}76 \%-100 \% \text { area } \\
\text { memiliki drainase } \\
\text { lingkungan yang kotor } \\
\text { dan berbau }\end{array}$ & 5 & 5 \\
\hline & & $\begin{array}{l}51 \%-75 \% \text { area memiliki } \\
\text { drainase lingkungan } \\
\text { yang kotor dan berbau }\end{array}$ & 3 & \\
\hline & & $\begin{array}{l}25 \%-50 \% \text { area memiliki } \\
\text { drainase lingkungan } \\
\text { yang kotor dan berbau }\end{array}$ & 1 & \\
\hline \multirow{3}{*}{$\begin{array}{l}\text { Kualitas Konstruksi } \\
\text { Drainase }\end{array}$} & \multirow{3}{*}{$\begin{array}{l}\text { Kualitas konstruksi drainase } \\
\text { buruk, karena berupa galian } \\
\text { tanah tanpa material pelapis atau } \\
\text { penutup maupun karena telah } \\
\text { terjadi kerusakan }\end{array}$} & $\begin{array}{l}76 \%-100 \% \text { area } \\
\text { memiliki kualitas } \\
\text { kontrsuksi drainase } \\
\text { lingkungan buruk }\end{array}$ & 5 & 5 \\
\hline & & $\begin{array}{l}51 \%-75 \% \text { area memiliki } \\
\text { kualitas kontrsuksi } \\
\text { drainase lingkungan } \\
\text { buruk }\end{array}$ & 3 & \\
\hline & & $\begin{array}{l}25 \%-50 \% \text { area memiliki } \\
\text { kualitas kontrsuksi } \\
\text { drainase lingkungan } \\
\text { buruk }\end{array}$ & 1 & \\
\hline \multirow{3}{*}{$\begin{array}{l}\text { Sistem Pengelolaan } \\
\text { Air Limbah Tidak } \\
\text { Sesuai Standar } \\
\text { Teknis }\end{array}$} & \multirow{3}{*}{$\begin{array}{l}\text { Pengelolaan air limbah pada } \\
\text { lokasi perumahan atau } \\
\text { permukiman tidak memiliki } \\
\text { sistem yang memadai, } \\
\text { yaitukakus/kloset yang tidak } \\
\text { terhubung dengan tangki septik } \\
\text { baik secara individual, komunal } \\
\text { maupun terpusat. }\end{array}$} & $\begin{array}{l}76 \%-100 \% \text { area } \\
\text { memiliki sistem air } \\
\text { limbah yang tidak sesuai } \\
\text { standar teknis }\end{array}$ & 5 & 5 \\
\hline & & $\begin{array}{l}51 \%-75 \% \text { area memiliki } \\
\text { sistem air limbah yang } \\
\text { tidak sesuai standar } \\
\text { teknis }\end{array}$ & 3 & \\
\hline & & $\begin{array}{l}25 \%-50 \% \text { area memiliki } \\
\text { sistem air limbah yang } \\
\text { tidak sesuai standar } \\
\text { teknis }\end{array}$ & 1 & \\
\hline $\begin{array}{l}\text { Prasarana dan } \\
\text { Sarana Pengelolaan } \\
\text { Air Limbah Tidak }\end{array}$ & $\begin{array}{l}\text { Kondisi prasarana dan sarana } \\
\text { pengelolaan air limbah pada } \\
\text { lokasi perumahan atau }\end{array}$ & $\begin{array}{l}76 \%-100 \% \text { area } \\
\text { memiliki sarpras air } \\
\text { limbah tidak sesuai }\end{array}$ & 5 & \\
\hline
\end{tabular}




\begin{tabular}{|c|c|c|c|c|}
\hline Kriteria & Indikator & Parameter & Nilai & $\begin{array}{c}\text { Kel } \\
\text { Bangun } \\
\text { Jaya } \\
\end{array}$ \\
\hline \multirow{3}{*}{$\begin{array}{l}\text { Sesuai dengan } \\
\text { Persyaratan Teknis }\end{array}$} & \multirow{3}{*}{$\begin{array}{l}\text { permukiman dimana: } \\
\text { 1. kloset leher angsa tidak } \\
\text { terhubung dengan tangki septik; } \\
\text { 2. tidak tersedianya sistem } \\
\text { pengolahan limbah setempat } \\
\text { atau terpusat }\end{array}$} & persyaratan teknis & & \\
\hline & & $\begin{array}{l}51 \%-75 \% \text { area memiliki } \\
\text { sarpras air limbah tidak } \\
\text { sesuai persyaratan teknis }\end{array}$ & 3 & 3 \\
\hline & & $\begin{array}{l}25 \%-50 \% \text { area memiliki } \\
\text { sarpras air limbah tidak } \\
\text { sesuai persyaratan teknis }\end{array}$ & 1 & \\
\hline \multirow{3}{*}{$\begin{array}{l}\text { Prasarana dan } \\
\text { Sarana } \\
\text { Persampahan Tidak } \\
\text { Sesuai dengan } \\
\text { Persyaratan Teknis }\end{array}$} & \multirow{3}{*}{$\begin{array}{l}\text { Prasarana dan sarana } \\
\text { persampahan pada lokasi } \\
\text { perumahan atau permukiman } \\
\text { tidak sesuai dengan persyaratan } \\
\text { teknis, yaitu: } \\
\text { 1. tempat sampah dengan } \\
\text { pemilahan sampah pada skala } \\
\text { domestik atau rumah tangga; } \\
\text { 2. tempat pengumpulan sampah } \\
\text { (TPS) atau TPS 3R (reduce, reuse, } \\
\text { recycle) pada skala lingkungan; } \\
\text { 3. Gerobak sampah dan/atau truk } \\
\text { sampah pada skala lingkungan; } \\
\text { dan } \\
\text { 4. Tempat pengolahan sampah } \\
\text { terpadu (TPST) pada skala } \\
\text { lingkungan. }\end{array}$} & $\begin{array}{l}76 \%-100 \% \text { area } \\
\text { memiliki sarpras } \\
\text { pengelolaan } \\
\text { persampahan yang tidak } \\
\text { memenuhi persyaratan } \\
\text { teknis }\end{array}$ & 5 & \\
\hline & & $\begin{array}{l}51 \%-75 \% \text { area memiliki } \\
\text { sarpras pengelolaan } \\
\text { persampahan yang tidak } \\
\text { memenuhi persyaratan } \\
\text { teknis }\end{array}$ & 3 & 3 \\
\hline & & $\begin{array}{l}25 \%-50 \% \text { area memiliki } \\
\text { sarpras pengelolaan } \\
\text { persampahan yang tidak } \\
\text { memenuhi persyaratan } \\
\text { teknis }\end{array}$ & 1 & \\
\hline \multirow{3}{*}{$\begin{array}{l}\text { Sistem Pengelolaan } \\
\text { Persampahan yang } \\
\text { Tidak Sesuai } \\
\text { Standar Teknis }\end{array}$} & \multirow{3}{*}{$\begin{array}{l}\text { Pengelolaan persampahan pada } \\
\text { lingkungan perumahan atau } \\
\text { permukiman tidak memenuhi } \\
\text { persyaratan sebagai berikut: } \\
\text { 1. pewadahan dan pemilahan } \\
\text { 111a katas; } \\
\text { 2. pengumpulan lingkungan; } \\
\text { 3. pengangkutan lingkungan; } \\
\text { 4. pengolahan lingkungan }\end{array}$} & $\begin{array}{l}76 \%-100 \% \text { area } \\
\text { memiliki sistem } \\
\text { persampahan tidak } \\
\text { sesuai standar }\end{array}$ & 5 & 5 \\
\hline & & $\begin{array}{l}51 \%-75 \% \text { area memiliki } \\
\text { sistem persampahan } \\
\text { tidak sesuai standar }\end{array}$ & 3 & \\
\hline & & $\begin{array}{l}25 \%-50 \% \text { area memiliki } \\
\text { sistem persampahan } \\
\text { tidak sesuai standar }\end{array}$ & 1 & \\
\hline \multirow{3}{*}{$\begin{array}{l}\text { Tidakterpeliharanya } \\
\text { Sarana dan } \\
\text { Prasarana } \\
\text { Pengelolaan } \\
\text { Persampahan }\end{array}$} & \multirow{3}{*}{$\begin{array}{l}\text { Tidak dilakukannya } \\
\text { pemeliharaan sarana dan } \\
\text { prasarana pengelolaan } \\
\text { persampahan pada lokasi } \\
\text { perumahan atau permukiman, } \\
\text { baik: } \\
\text { 1. pemeliharaan rutin; dan/atau } \\
\text { 2. pemeliharaan berkala }\end{array}$} & $\begin{array}{l}76 \%-100 \% \text { area } \\
\text { memiliki sarpras } \\
\text { persampahan yang tidak } \\
\text { terpelihara }\end{array}$ & 5 & 5 \\
\hline & & $\begin{array}{l}51 \%-75 \% \text { area memiliki } \\
\text { sarpras persampahan } \\
\text { yang tidak terpelihara }\end{array}$ & 3 & \\
\hline & & $\begin{array}{l}25 \%-50 \% \text { area memiliki } \\
\text { sarpras persampahan } \\
\text { yang tidak terpelihara }\end{array}$ & 1 & \\
\hline \multirow[t]{2}{*}{$\begin{array}{l}\text { Ketidaktersediaan } \\
\text { Prasarana Proteksi } \\
\text { Kebakaran }\end{array}$} & \multirow{2}{*}{$\begin{array}{l}\text { Tidak tersedianya prasarana } \\
\text { proteksi kebakaran pada lokasi, } \\
\text { yaitu: } \\
\text { 1. pasokan air; } \\
\text { 2. jalan lingkungan; } \\
\text { 3. sarana komunikasi; }\end{array}$} & $\begin{array}{l}76 \% \text { - } 100 \% \text { area tidak } \\
\text { memiliki prasarana } \\
\text { proteksi kebakaran }\end{array}$ & 5 & \\
\hline & & $\begin{array}{l}51 \%-75 \% \text { area tidak } \\
\text { memiliki prasarana } \\
\text { proteksi kebakaran }\end{array}$ & 3 & 3 \\
\hline
\end{tabular}




\begin{tabular}{|c|c|c|c|c|}
\hline Kriteria & Indikator & Parameter & Nilai & $\begin{array}{c}\text { Kel } \\
\text { Bangun } \\
\text { Jaya }\end{array}$ \\
\hline & $\begin{array}{l}\text { 4. data sistem proteksi kebakaran } \\
\text { lingkungan; dan } \\
\text { 5. bangunan pos kebakaran }\end{array}$ & $\begin{array}{l}25 \%-50 \% \text { area tidak } \\
\text { memiliki prasarana } \\
\text { proteksi kebakaran }\end{array}$ & 1 & \\
\hline \multirow{3}{*}{$\begin{array}{l}\text { Ketidaktersediaan } \\
\text { Sarana Proteksi } \\
\text { Kebakaran }\end{array}$} & \multirow{3}{*}{$\begin{array}{l}\text { Tidak tersedianya sarana } \\
\text { proteksi kebakaran pada lokasi, } \\
\text { yaitu: } \\
\text { 1. Alat Pemadam Api Ringan } \\
\text { (APAR); } \\
\text { 2. mobil pompa; } \\
\text { 3. mobil tangga sesuai } \\
\text { kebutuhan; dan } \\
\text { 4. peralatan pendukung lainnya }\end{array}$} & $\begin{array}{l}76 \%-100 \% \text { area tidak } \\
\text { memiliki sarana proteksi } \\
\text { kebakaran }\end{array}$ & 5 & 5 \\
\hline & & $\begin{array}{l}51 \%-75 \% \text { area tidak } \\
\text { memiliki sarana proteksi } \\
\text { kebakaran }\end{array}$ & 3 & \\
\hline & & $\begin{array}{l}25 \%-50 \% \text { area tidak } \\
\text { memiliki sarana proteksi } \\
\text { kebakaran }\end{array}$ & 1 & \\
\hline \multirow[b]{2}{*}{$\begin{array}{l}\text { Kejelasan Status } \\
\text { Penguasaan tanah }\end{array}$} & \multirow{2}{*}{$\begin{array}{l}\text { Kejelasan terhadap status } \\
\text { penguasaan tanah berupa: } \\
\text { 1. kepemilikan sendiri, dengan } \\
\text { bukti dokumen sertifikat hak atas } \\
\text { tanah atau bentuk dokumen } \\
\text { keterangan status tanah lainnya } \\
\text { yang sah; atau } \\
\text { 2. kepemilikan pihak lain } \\
\text { (termasuk milik adat/ulayat), } \\
\text { dengan bukti izin pemanfaatan } \\
\text { tanah dari pemegang hak atas } \\
\text { tanah atau pemilik tanah dalam } \\
\text { bentuk perjanjian tertulis antara } \\
\text { pemegang hak atas tanah atau } \\
\text { pemilik tanah dengan }\end{array}$} & $\begin{array}{l}\text { Keseluruhan lokasi } \\
\text { memiliki kejelasan status } \\
\text { penguasaan tanah, baik } \\
\text { milik sendiri atau milik } \\
\text { pihak lain }\end{array}$ & + & \\
\hline & & $\begin{array}{l}\text { Sebagian atau } \\
\text { keseluruhan lokasi tidak } \\
\text { memiliki kejelasan status } \\
\text { penguasaan tanah, baik } \\
\text { milik sendiri atau milik } \\
\text { pihak lain }\end{array}$ & - & - \\
\hline \multirow{2}{*}{ Kesesuaian RTR } & \multirow{2}{*}{$\begin{array}{l}\text { Kesesuaian terhadap peruntukan } \\
\text { lahan dalam rencana tata ruang } \\
\text { (RTR), dengan bukti Izin } \\
\text { Mendirikan Bangunan atau Surat } \\
\text { Keterangan Rencana } \\
\text { Kabupaten/Kota (SKRK). }\end{array}$} & $\begin{array}{l}\text { Keseluruhan lokasi } \\
\text { berada pada zona } \\
\text { peruntukan } \\
\text { perumahan/permukiman } \\
\text { sesuai RTR }\end{array}$ & + & + \\
\hline & & $\begin{array}{l}\text { Sebagian atau } \\
\text { keseluruhan lokasi } \\
\text { berada bukan pada zona } \\
\text { peruntukan } \\
\text { perumahan/permukiman } \\
\text { sesuai RTR }\end{array}$ & - & \\
\hline \multirow{2}{*}{$\begin{array}{l}\text { Nilai Strategis } \\
\text { Lokasi }\end{array}$} & \multirow{2}{*}{$\begin{array}{l}\text { Pertimbangan letak lokasi } \\
\text { perumahan atau permukiman } \\
\text { pada: } \\
\text { 1. fungsi strategis } \\
\text { kabupaten/kota; atau } \\
\text { 2. bukan fungsi strategis } \\
\text { kabupaten/kota }\end{array}$} & $\begin{array}{l}\text { Lokasi terletak pada } \\
\text { fungsi strategis } \\
\text { kabupaten/kota } \\
\end{array}$ & 5 & 5 \\
\hline & & $\begin{array}{l}\text { Lokasi tidak terletak } \\
\text { pada fungsi strategis } \\
\text { kabupaten/kota }\end{array}$ & 1 & \\
\hline \multirow[t]{2}{*}{ Kependudukan } & \multirow{2}{*}{$\begin{array}{l}\text { Pertimbangan kepadatan } \\
\text { penduduk pada lokasi } \\
\text { perumahan atau permukiman } \\
\text { dengan klasifikasi: } \\
\text { 1. rendah yaitu kepadatan }\end{array}$} & $\begin{array}{l}\text { Kepadatan Penduduk } \\
\text { pada Lokasi sebesar } \\
>200 \text { Jiwa/Ha }\end{array}$ & 5 & \\
\hline & & $\begin{array}{l}\text { Kepadatan Penduduk } \\
\text { pada Lokasi sebesar } 151\end{array}$ & 3 & 3 \\
\hline
\end{tabular}




\begin{tabular}{|c|c|c|c|c|}
\hline Kriteria & Indikator & Parameter & Nilai & $\begin{array}{c}\text { Kel } \\
\text { Bangun } \\
\text { Jaya } \\
\end{array}$ \\
\hline & \multirow[b]{2}{*}{$\begin{array}{l}\text { penduduk di bawah } 150 \text { jiwa/ha; } \\
\text { 2. sedang yaitu kepadatan } \\
\text { penduduk antara } 151-200 \\
\text { jiwa/ha; } \\
\text { 3. tinggi yaitu kepadatan } \\
\text { penduduk antara } 201-400 \\
\text { jiwa/ha; } \\
\text { 4. sangat padat yaitu kepadatan } \\
\text { penduduk di atas } 400 \text { jiwa/ha; }\end{array}$} & - 200 Jiwa/Ha & & \\
\hline & & $\begin{array}{l}\text { Kepadatan Penduduk } \\
\text { pada Lokasi sebesar } \\
<150 \text { Jiwa/Ha }\end{array}$ & 1 & \\
\hline \multirow{2}{*}{$\begin{array}{l}\text { Kondisi Sosial, } \\
\text { Ekonomi, dan } \\
\text { Budaya }\end{array}$} & \multirow{2}{*}{$\begin{array}{l}\text { Pertimbangan potensi yang } \\
\text { dimiliki lokasi perumahan atau } \\
\text { permukiman berupa: } \\
\text { 1. potensi sosial yaitu tingkat } \\
\text { partisipasi masyarakat dalam } \\
\text { mendukung pembangunan; } \\
\text { 2. potensi ekonomi yaitu adanya } \\
\text { kegiatan ekonomi tertentu yang } \\
\text { bersifat strategis bagi } \\
\text { masyarakat setempat; } \\
\text { 3. potensi budaya yaitu adanya } \\
\text { kegiatan atau warisan budaya } \\
\text { tertentu yang dimiliki } \\
\text { masyarakat setempat. }\end{array}$} & $\begin{array}{l}\text { Lokasi memiliki potensi } \\
\text { sosial, ekonomi dan } \\
\text { budaya untuk } \\
\text { dikembangkan atau } \\
\text { dipelihara }\end{array}$ & 5 & \\
\hline & & $\begin{array}{l}\text { Lokasi tidak memiliki } \\
\text { potensi sosial, ekonomi } \\
\text { dan budaya tinggi untuk } \\
\text { dikembangkan atau } \\
\text { dipelihara }\end{array}$ & 1 & 1 \\
\hline
\end{tabular}

Sumber: Hasil Analisa, 2018

Berdasarkan hasil survey dan analisa, kemudian dilakukan pemetaan tipologi dan lokasi kawasan kumuh di Kelurahan Muara Lakitan dan Bangun Jaya, seperti yang terlihat pada Gambar 2 dan Gambar 3.
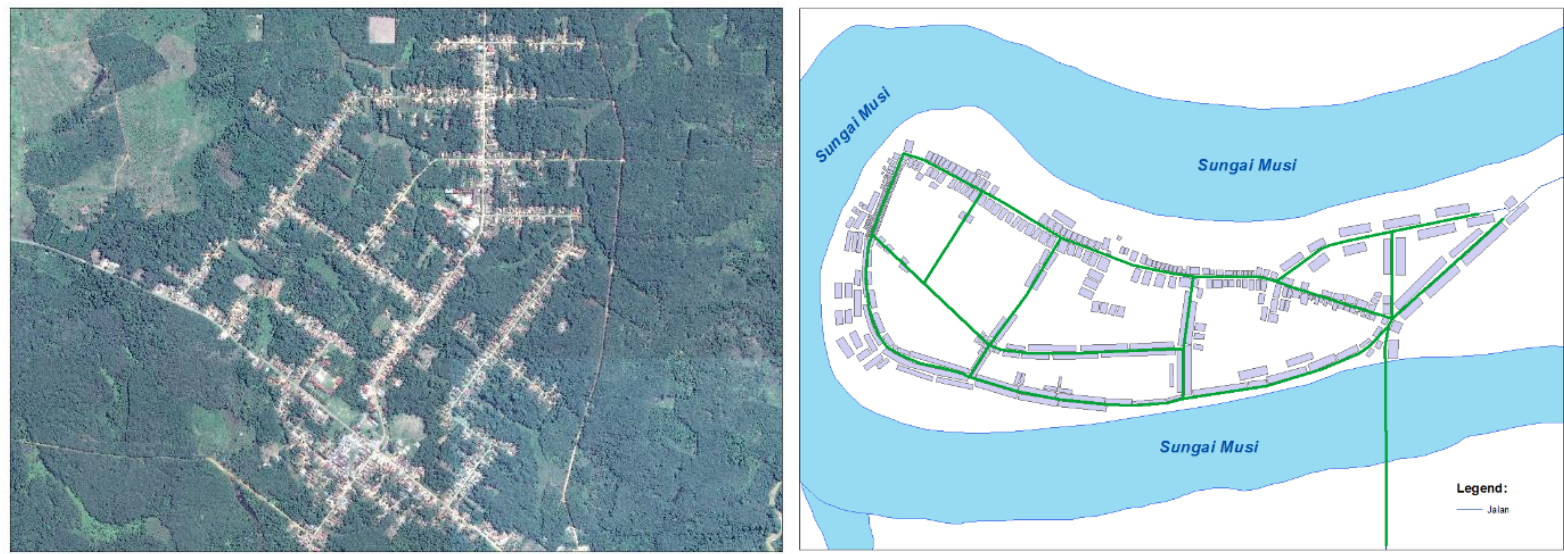

Gambar 2. Tipologi Kawasan Kelurahan Bangun Jaya (kiri) dan Kelurahan Muara Lakitan (kanan) 

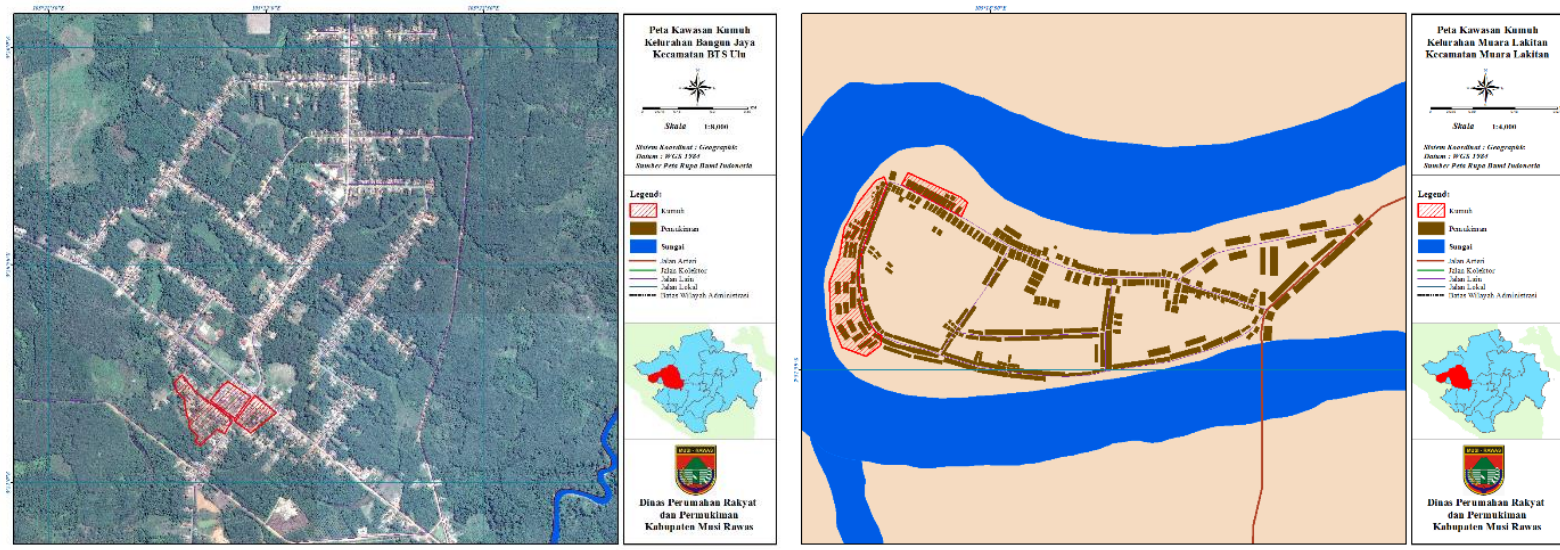

Gambar 3. Peta Kawasan Kumuh di Kelurahan Bangun Jaya (Kiri) dan Muara Lakitan (Kanan)

Berdasarkan Peraturan Menteri Pekerjaan Umum dan Perumahan Rakyat No. 2 Tahun 2016 tentang Peningkatan Kualitas Terhadap Perumahan Kumuh dan Permukiman Kumuh, hasil analisa menunjukkan bahwa tingkat kekumuhan pada Kelurahan Bangun Jaya Kecamatan BTS Ulu menunjukkan tingkat Kekumuhan Sedang dengan total nilai kondisi kekumuhan 69, Nilai 9 untuk tingkat sedang pada kriteria pertimbangan lain, dan status tanah tidak legal dalam hal ini dikarena membangun pada lahan tidak sesuai peruntukkan.

Sedangkan tingkat kekumuhan pada Kelurahan Muara Lakitan Kecamatan Muara lakitan menunjukkan tingkat Kekumuhan Sedang dengan total nilai kondisi kekumuhan 69, Nilai 9 untuk tingkat sedang pada kriteria pertimbangan lain, dan status tanah tidak legal dalam hal ini dikarena membangun pada lahan tidak sesuai peruntukkan.

\section{KESIMPULAN}

Berdasarkan tingkat kekumuhan sedang pada wilayah Kelurahan Bangun Jaya dan Muara Lakitan maka pemerintah daerah Kabupaten Musi Rawas, dalam hal ini Dinas Perumahan Rakyat dan Permukiman dapat melakukan penataan terhadap kawasan - kawasan yang dinyatakan kumuh dengan menitik beratkan pada indikator - indikator penyebab kekumuhan yang dominan.

\section{UCAPAN TERIMA KASIH}

Ucapan terimakasih dapat diberikan kepada Universitas Indo Global Mandiri sebagai pelindung dalam kegiatan ini, Pemerintah Kabupaten Musi Rawas (Dinas Perumahan dan Permukiman) atas kesempatan melalukan kegiatan ini, aparat setempat dan masyarakat Kelurahan Bangun Jaya Kecamatan BTS Ulu dan Kelurahan Muara Lakitan Kecamatan Muara Lakitan sebagai tempat dilakukannya kegiatan pengabdian kepada masyarakat ini.

\section{DAFTAR PUSTAKA}

Peraturan Pemerintah No. 14 Tahun 2014 tentang Pembinaan Penyelenggaraan Perumahan dan Kawasan Permukiman;

Peraturan Menteri No. 2 Tahun 2016 tentang Peningkatan Kualitas Terhadap Perumahan Kumuh dan Permukiman Kumuh

BPS Kabupaten Musi Rawas, Kabupaten Musi Rawas dalam Angka Tahun 2017.

BPS Kabupaten Musi Rawas, Bangun Jaya dalam Angka Tahun 2017.

BPS Kabupaten Musi Rawas, Muara Lakitan dalam Angka Tahun 2017. 